Supporting Information

\title{
Efficient synthesis of icetexane diterpenes and apoptosis inducing effect by upregulating BiP-ATF4-CHOP axis in colorectal cells
}

Wei Cao, $† \#$ Tingting Liu, $† \#$ Shuting Yang, $\uparrow$ Moude Liu,,$\uparrow$ Zhenghong Pan, $\S$ Yingjun

$$
\text { Zhou, }{ }^{*} \uparrow, \text { II Xu Deng } *,+, \text { I }
$$

$\uparrow$ Xiangya School of Pharmaceutical Science, Central South University, Changsha 410013, Hunan, China

$\S$ Guangxi Key laboratory of Functional Phytochemicals Research and Utilization, Guangxi Institute of Botany, Guangxi Zhuang Autonomous Region and Chinese Academy of Sciences, Guilin 541006, China

ब Hunan Key laboratory of Diagnostic and Therapeutic Drug Research for Chronic Diseases, Central South University, Changsha, 410013, Hunan, China

Email: zhouyingjun@,csu.edu.cn, dengxu3817@csu.edu.cn

${ }^{1}$ These authors contribute equally to this work.

\section{Table of contents}

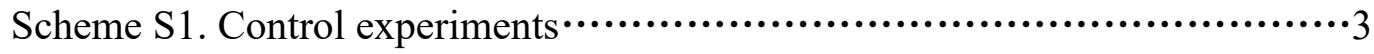

Scheme S2. Plausible mechanism for the $\mathrm{PPh}_{3} / \mathrm{DIAD}$-mediated rearrangement $\cdots 4$

Figure S1. The stability of $(+)$-grandione $(11)$ in cell culture $\cdots \cdots \cdots \cdots \cdots \cdots \cdots \cdots \cdots \cdots \cdots \cdots$

Figure S2. The ${ }^{1} \mathrm{H}$ NMR spectrum of carnosic acid methyl ester in $\mathrm{CDCl}_{3}$ (400 $\mathrm{MHz}) \cdots 7$

Figure S3. The ${ }^{13} \mathrm{C}$ NMR spectrum of carnosic acid methyl ester in $\mathrm{CDCl}_{3}$ (101 $\mathrm{MHz}) \cdots 7$

Figure S4. The ${ }^{1} \mathrm{H}$ NMR spectrum of compound 2 in DMSO- $d_{6}(400 \mathrm{MHz}) \cdots \cdots \cdot 8$

Figure S5. The ${ }^{13} \mathrm{C}$ NMR spectrum of compound 2 in DMSO- $d_{6}(101 \mathrm{MHz}) \cdots \cdots 8$

Figure S6. The ${ }^{1} \mathrm{H}$ NMR spectrum of compound 3 in $\mathrm{CDCl}_{3}(400 \mathrm{MHz}) \cdots \cdots \cdot \cdot 9$

Figure S7. The ${ }^{13} \mathrm{C}$ NMR spectrum of compound 3 in $\mathrm{CDCl}_{3}(101 \mathrm{MHz}) \cdots \cdots \cdot \cdot 9$

Figure S8. The ${ }^{1} \mathrm{H}$ NMR spectrum of compound 4 in $\mathrm{CDCl}_{3}(500 \mathrm{MHz}) \cdots \cdots \cdots \cdot 10$ 
Figure S9. The ${ }^{13} \mathrm{C}$ NMR spectrum of compound 4 in $\mathrm{CDCl}_{3}(126 \mathrm{MHz}) \cdots \cdots \cdots \cdot 10$

Figure S10. The ${ }^{1} \mathrm{H}$ NMR spectrum of compound 5 in $\mathrm{CDCl}_{3}(400 \mathrm{MHz}) \cdots \cdots \cdots \cdot 11$

Figure S11. The ${ }^{13} \mathrm{C}$ NMR spectrum of compound 5 in $\mathrm{CDCl}_{3}(101 \mathrm{MHz}) \cdots \cdots \cdots \cdot 11$

Figure S12. The ${ }^{1} \mathrm{H}$ NMR spectrum of compound 6 in $\mathrm{CDCl}_{3}(500 \mathrm{MHz}) \cdots \cdots \cdots \cdot 12$

Figure S13. The ${ }^{13} \mathrm{C}$ NMR spectrum of compound 6 in $\mathrm{CDCl}_{3}(126 \mathrm{MHz}) \cdots \cdots \cdots \cdot 12$

Figure S14. The ${ }^{1} \mathrm{H}$ NMR spectrum of compound 7 in $\mathrm{CDCl}_{3}(400 \mathrm{MHz}) \cdots \cdots 13$

Figure S15. The ${ }^{13} \mathrm{C}$ NMR spectrum of compound 7 in $\mathrm{CDCl}_{3}(101 \mathrm{MHz}) \cdots \cdots \cdot 13$

Figure S16. The ${ }^{1} \mathrm{H}$ NMR spectrum of compound 8 in $\mathrm{CDCl}_{3}(400 \mathrm{MHz}) \cdots \cdots \cdot 14$

Figure S17. The ${ }^{13} \mathrm{C}$ NMR spectrum of compound 8 in $\mathrm{CDCl}_{3}(101 \mathrm{MHz}) \cdots \cdots \cdot 14$

Figure S18. The ${ }^{1} \mathrm{H}$ NMR spectrum of compound 9 in $\mathrm{CDCl}_{3}(400 \mathrm{MHz}) \cdots \cdots \cdot 15$

Figure S19. The ${ }^{13} \mathrm{C}$ NMR spectrum of compound 9 in $\mathrm{CDCl}_{3}(101 \mathrm{MHz}) \cdots \cdots \cdot 15$

Figure S20. The ${ }^{1} \mathrm{H}$ NMR spectrum of compound $\mathbf{1 0}$ in $\mathrm{CDCl}_{3}(400 \mathrm{MHz}) \cdots \cdots 16$

Figure S21. The ${ }^{13} \mathrm{C}$ NMR spectrum of compound 10 in $\mathrm{CDCl}_{3}(101 \mathrm{MHz}) \cdots \cdots \cdot 16$

Figure S22. The ${ }^{1} \mathrm{H}$ NMR spectrum of compound 11 in $\mathrm{CDCl}_{3}(400 \mathrm{MHz}) \cdots \cdots \cdot 17$

Figure S23. The ${ }^{13} \mathrm{C}$ NMR spectrum of compound 11 in $\mathrm{CDCl}_{3}(101 \mathrm{MHz}) \cdots \cdots \cdot 17$

Figure S24. The ${ }^{1} \mathrm{H}$ NMR spectrum of compound 12 in $\mathrm{CDCl}_{3}(500 \mathrm{MHz}) \cdots \cdots 18$

Figure S25. The ${ }^{13} \mathrm{C}$ NMR spectrum of compound 12 in $\mathrm{CDCl}_{3}(126 \mathrm{MHz}) \cdots \cdots \cdot 18$ 
Scheme S1. Control experiments

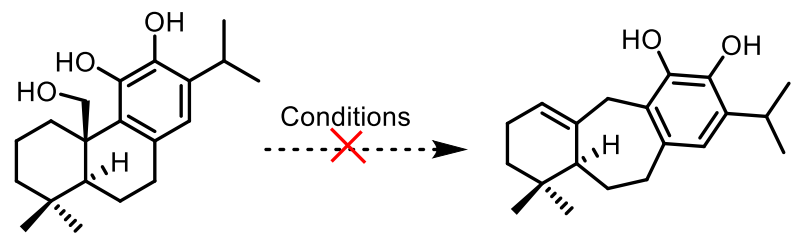

2

\begin{tabular}{lll} 
Conditions & Results \\
\hline 1 & $\mathrm{PPh}_{3}, \mathrm{THF}, \mathrm{rt} ;$ & $\mathrm{NR}$
\end{tabular}

(-)-Barbatusol (3)

2 DIAD, THF, rt; $\quad N R$<smiles></smiles>

2

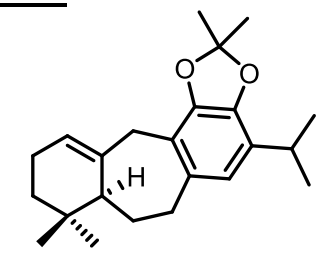

(-)-Barbatusol (3)

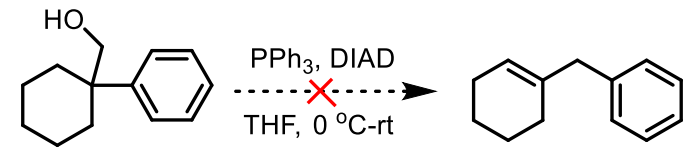

s1 $N R$ 
Scheme S2. Plausible mechanism for the $\mathrm{PPh}_{3} / \mathrm{DIAD}$-mediated rearrangement
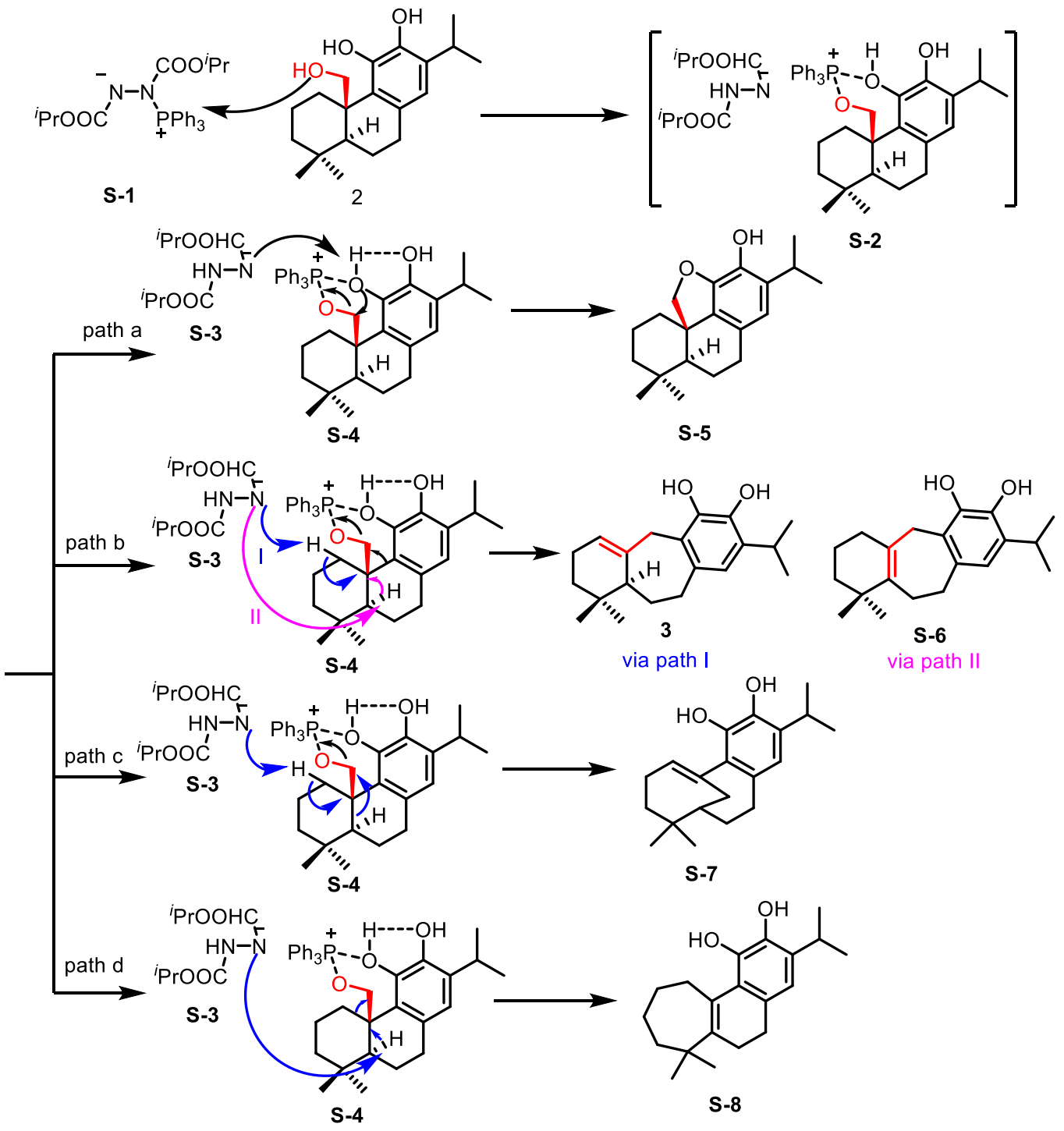
Figure S1. Stability of (+)-grandione (11) in cell culture
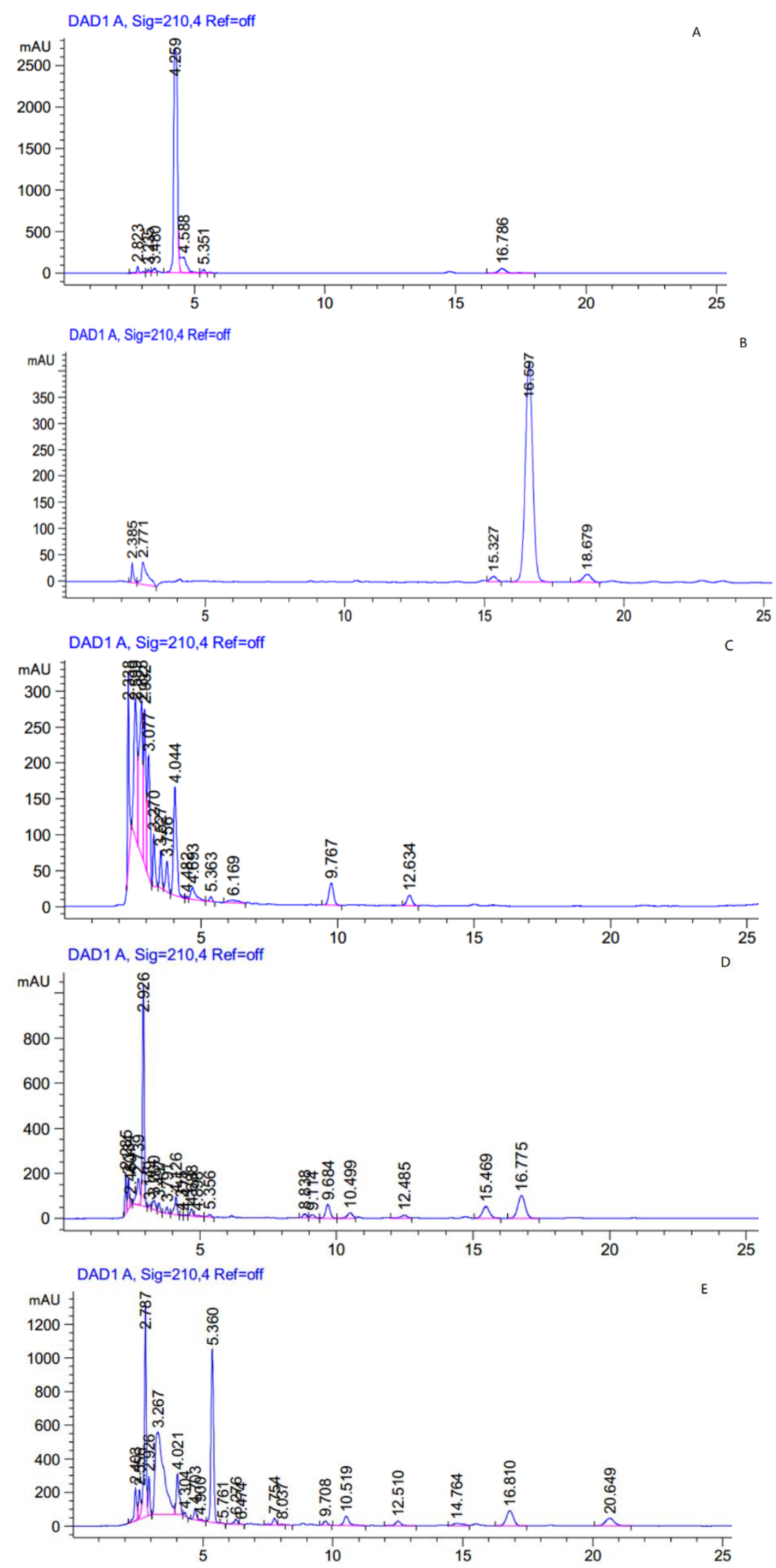


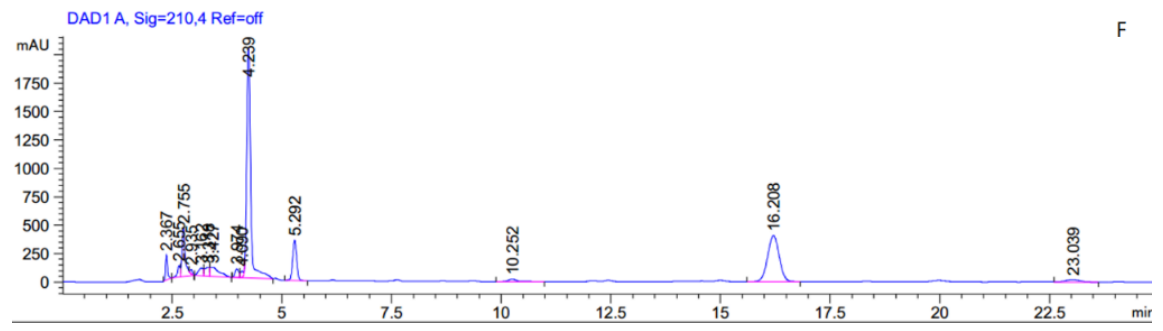

$(+)$-Grandione $(\mathbf{1 1}, 1.0 \mathrm{mg})$ was dissolved in DMSO $(80 \mu \mathrm{L})$. The solution $(40 \mu \mathrm{L})$ was incubated in complete DMEM culture with or without HCT-116 cells for 72 hours. The solution was then centrifuged at $3000 \mathrm{rpm}$ for $5 \mathrm{~min}$. The supernatant was diluted with $\mathrm{H}_{2} \mathrm{O}(10 \mathrm{~mL})$, which was extracted with $\mathrm{CH}_{2} \mathrm{Cl}_{2}(5 \mathrm{~mL} * 3)$. The combined organic layers were evaporated under vacuum. The residue was dissolved in $\mathrm{MeOH}(1 \mathrm{~mL})$ and was analyzed with HPLC. The HPLC analysis was performed on Waters Symmetry C18 column $(4.6 * 250 \mathrm{~mm}, 5 \mu \mathrm{m})$ with $\mathrm{CH}_{3} \mathrm{CN} / \mathrm{H}_{2} \mathrm{O}(95: 5)$ at $1.0 \mathrm{~mL} / \mathrm{min}$ and was detected at $210 \mathrm{nM}$. (A) Compound 9 alone was analyzed as the standard. (B) (+)-Grandione $\mathbf{1 1}$ alone was analyzed as the standard. (C) The supernatant of the blank group (HCT-116 cells without drug treatment) was analyzed as a control. (D) The complete DMEM culture without cells treated with (+)-Grandione (11) was analyzed. (E) The supernatant of HCT-116 cells treated with (+)-Grandione (11) was analyzed. (F) The supernatant of HCT-116 cells treated with $(+)$-Grandione (11) and additional portion of pure compounds 9 and $\mathbf{1 1}$ were added. The mixture was then analyzed. 
Figure S2. The ${ }^{1} \mathrm{H}$ NMR spectrum of carnosic acid methyl ester in $\mathrm{CDCl}_{3}(400$ MHz)

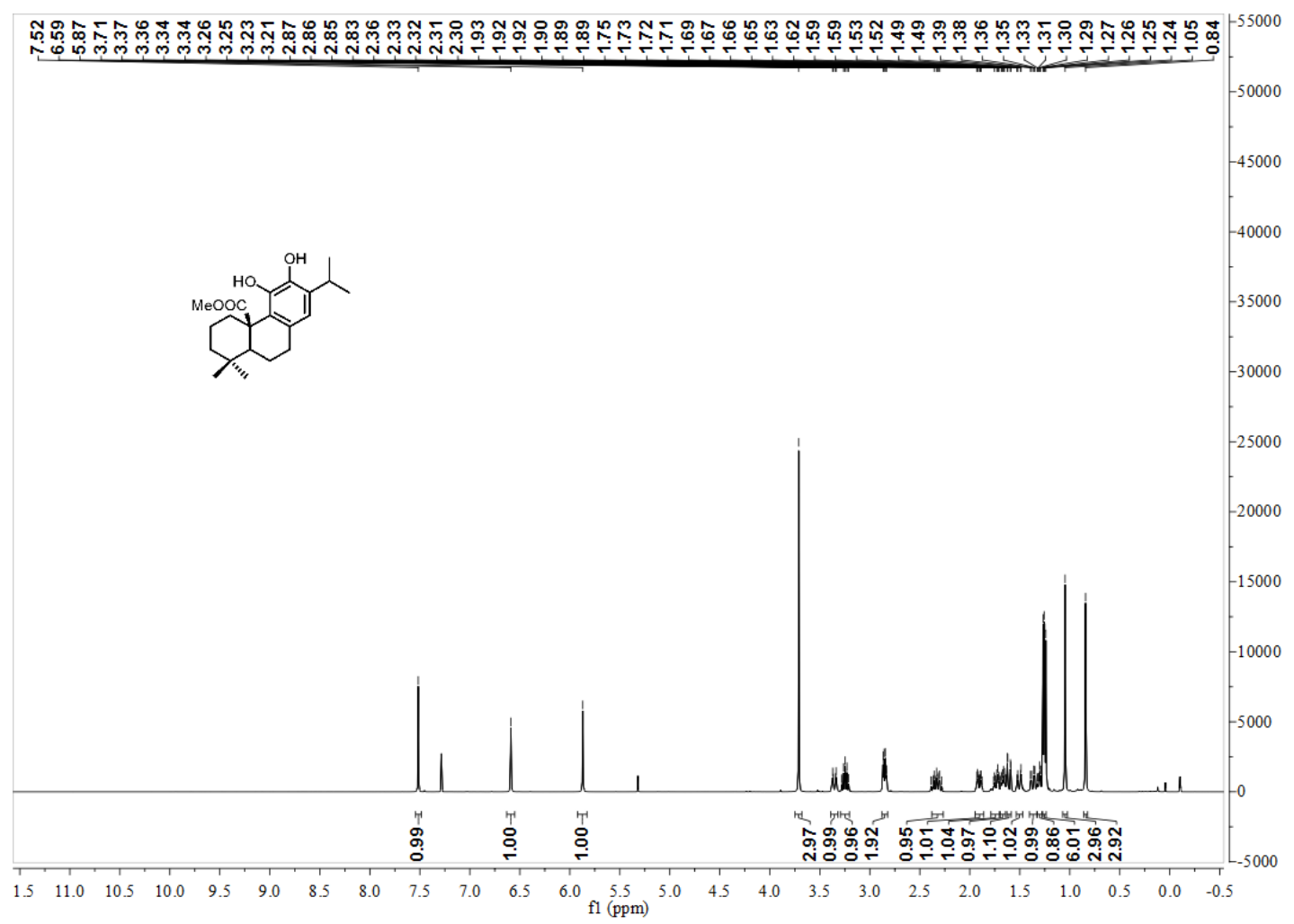

Figure S3. The ${ }^{13} \mathrm{C}$ NMR spectrum of carnosic acid methyl ester in $\mathrm{CDCl}_{3}(101$ MHz)

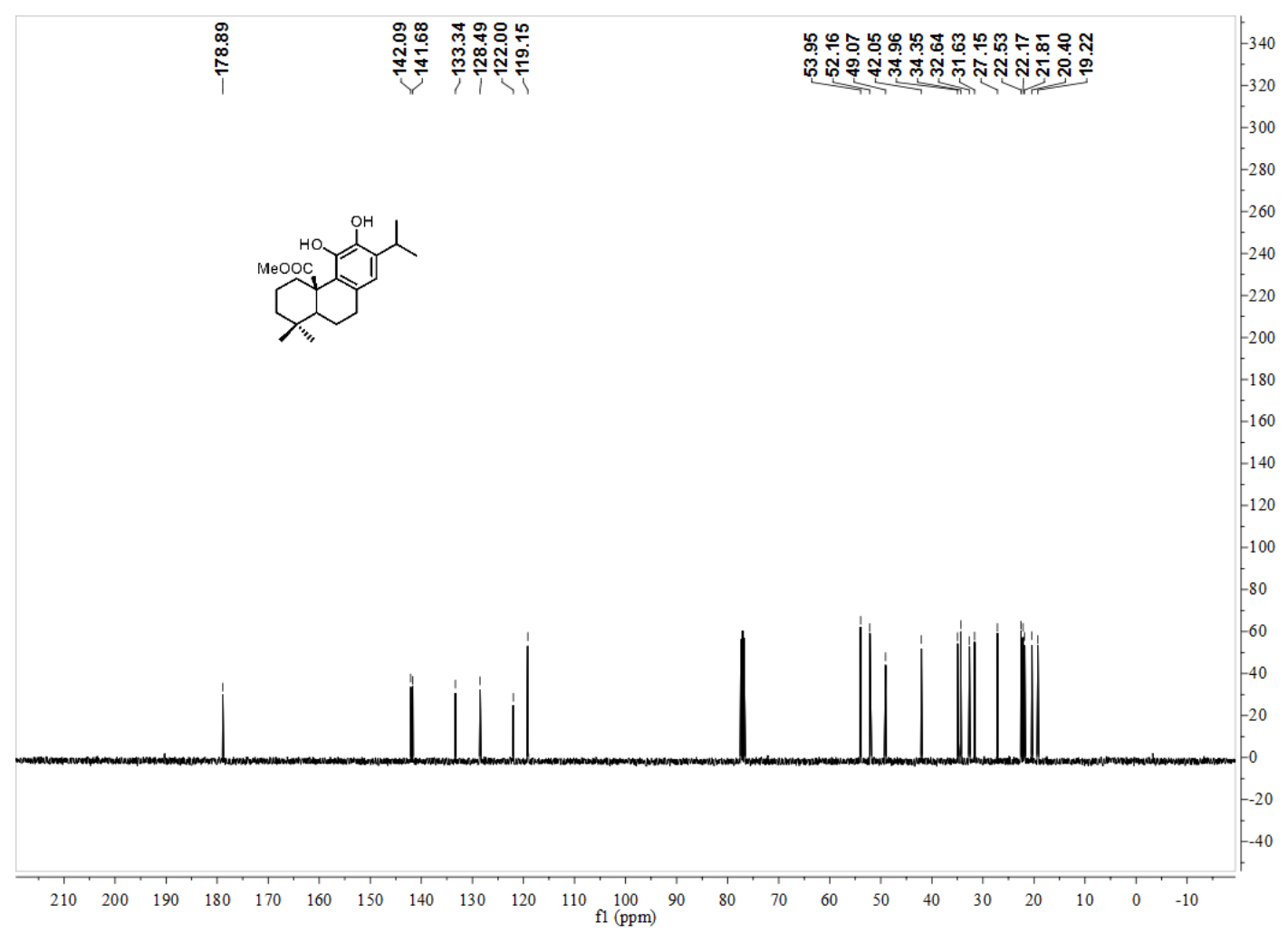


Figure S4. The ${ }^{1} \mathrm{H}$ NMR spectrum of compound 2 in DMSO-d $(400 \mathrm{MHz})$

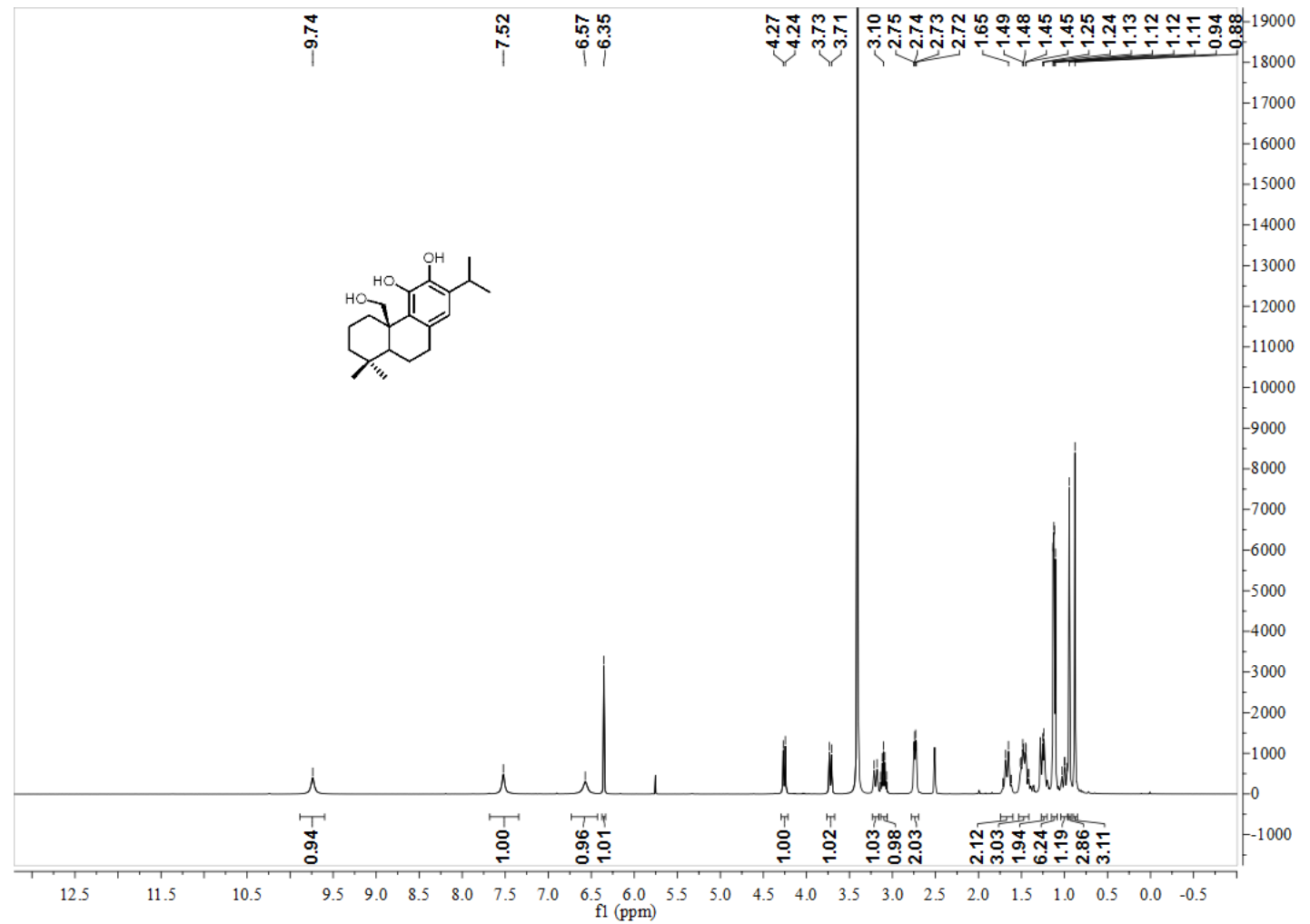

Figure S5. The ${ }^{13} \mathrm{C}$ NMR spectrum of compound 2 in DMSO-d6 (101 MHz)

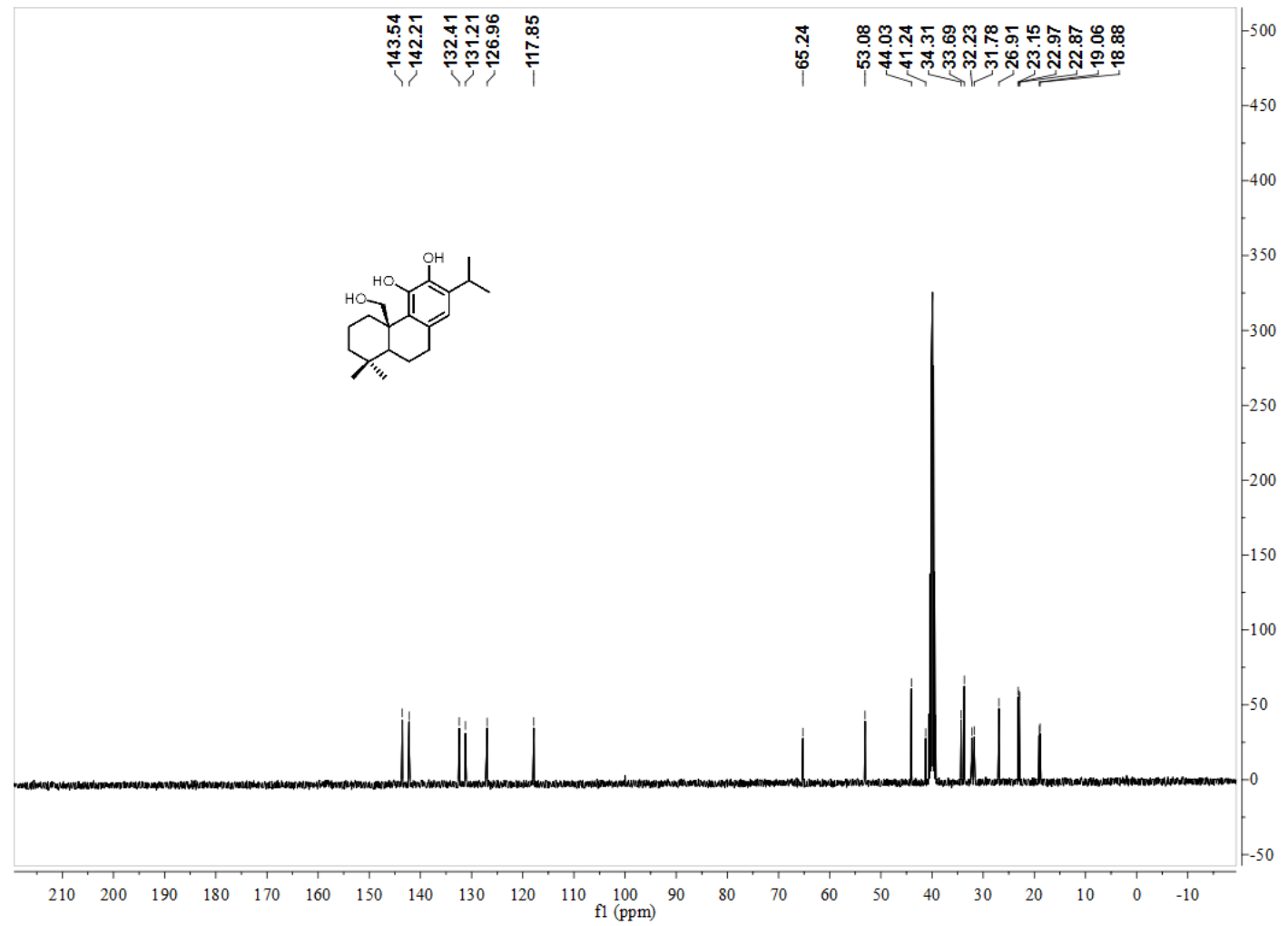


Figure S6. The ${ }^{1} \mathrm{H}$ NMR spectrum of compound 3 in $\mathrm{CDCl}_{3}(400 \mathrm{MHz})$

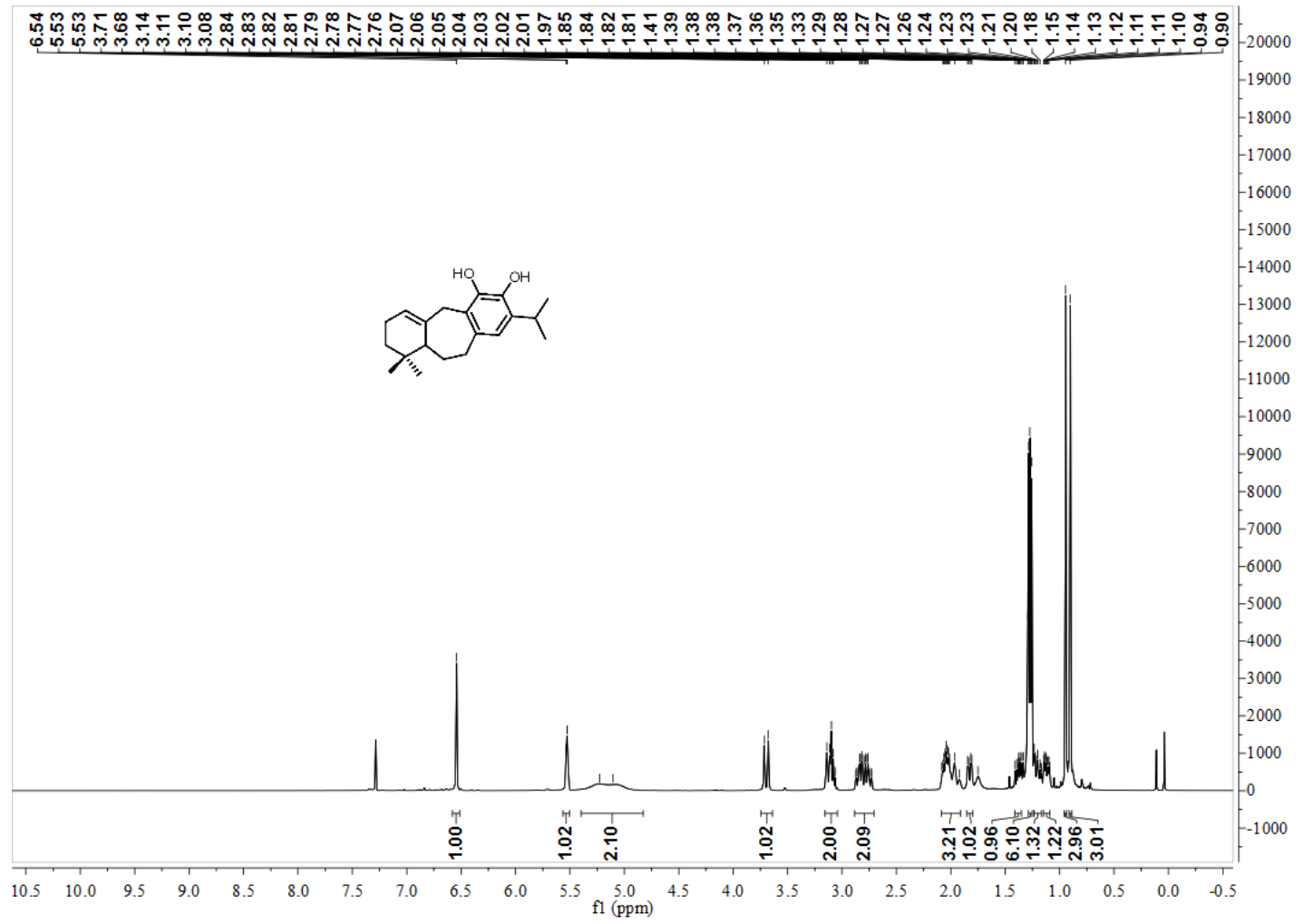

Figure S7. The ${ }^{13} \mathrm{C}$ NMR spectrum of compound 3 in $\mathrm{CDCl}_{3}(101 \mathrm{MHz})$

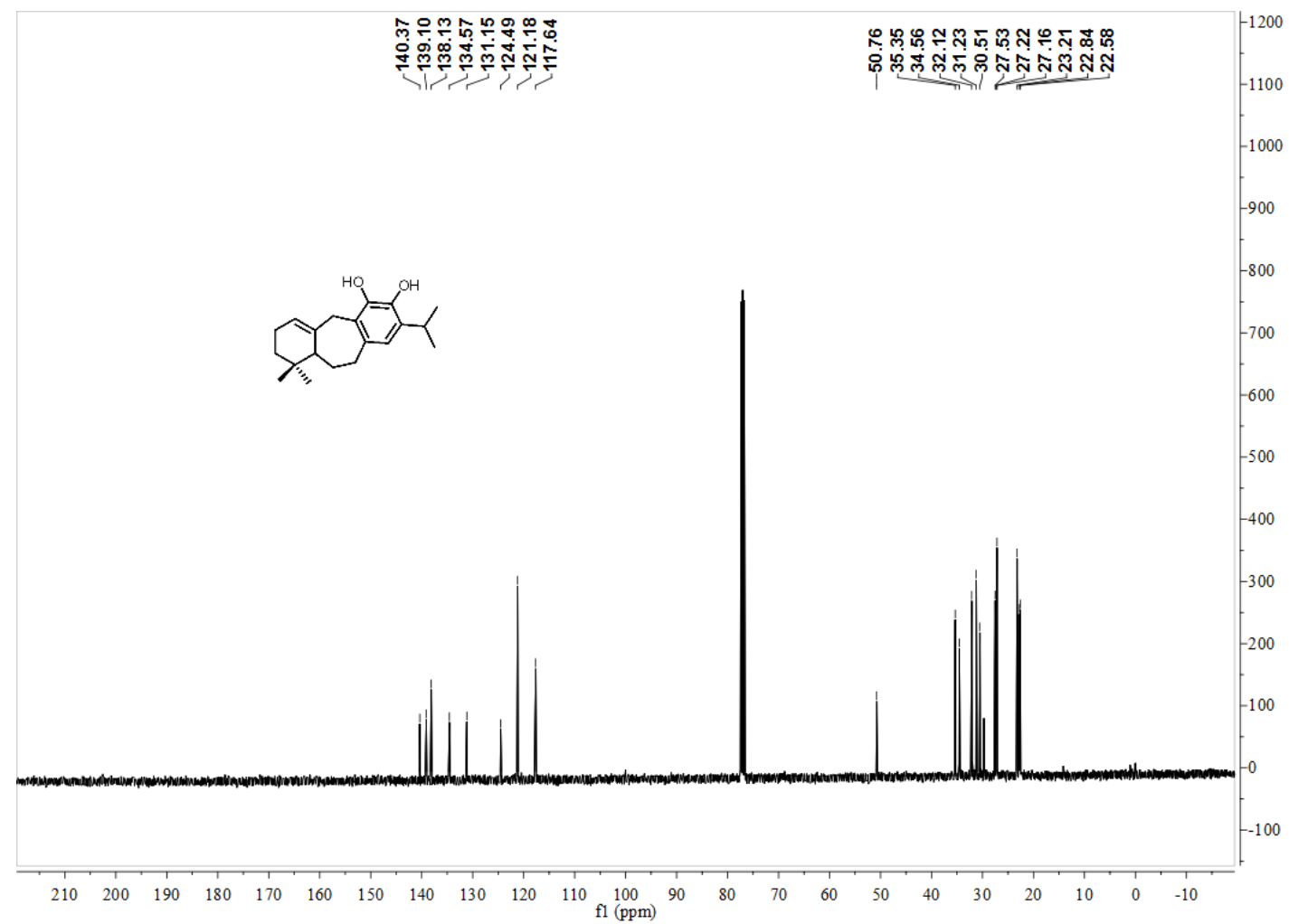


Figure S8. The ${ }^{1} \mathrm{H}$ NMR spectrum of compound 4 in $\mathrm{CDCl}_{3}(500 \mathrm{MHz})$

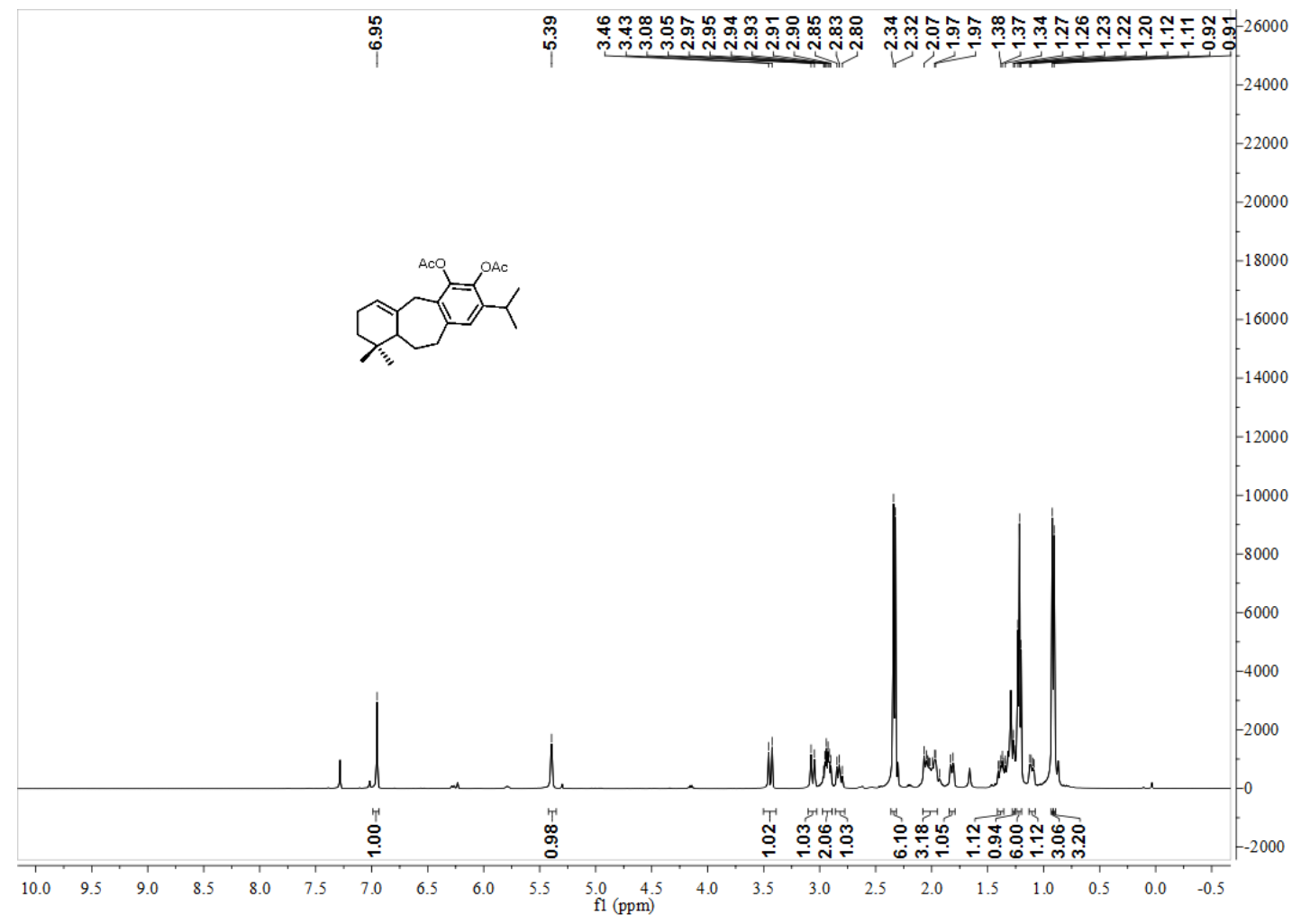

Figure S9. The ${ }^{13} \mathrm{C}$ NMR spectrum of compound 4 in $\mathrm{CDCl}_{3}(126 \mathrm{MHz})$

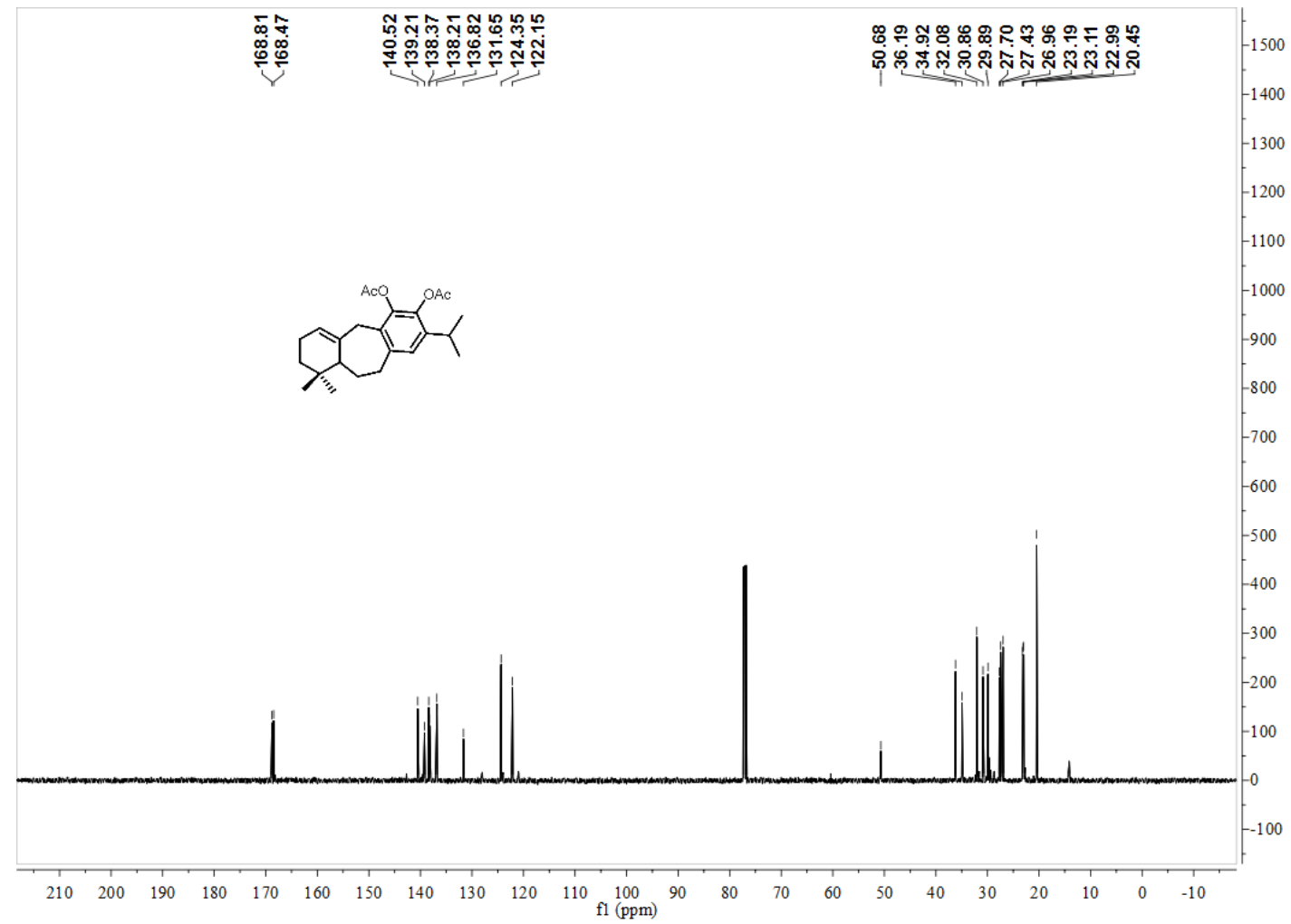


Figure S10. The ${ }^{1} \mathrm{H}$ NMR spectrum of compound 5 in $\mathrm{CDCl}_{3}(400 \mathrm{MHz})$

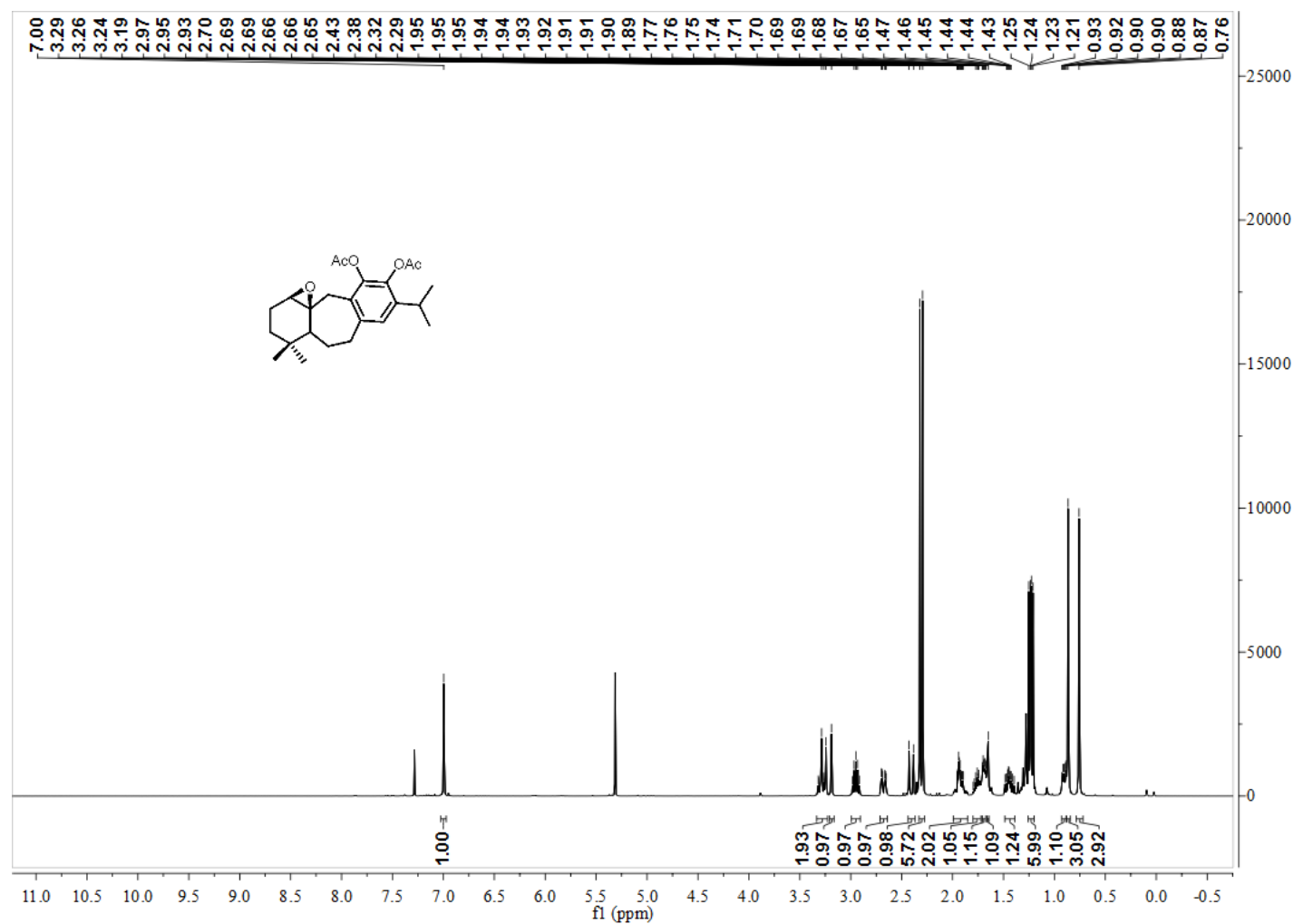

Figure S11. The ${ }^{13} \mathrm{C}$ NMR spectrum of compound 5 in $\mathrm{CDCl}_{3}(101 \mathrm{MHz})$

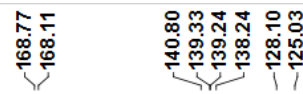

뚱ํำ

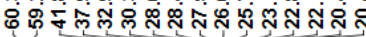

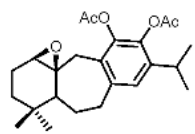

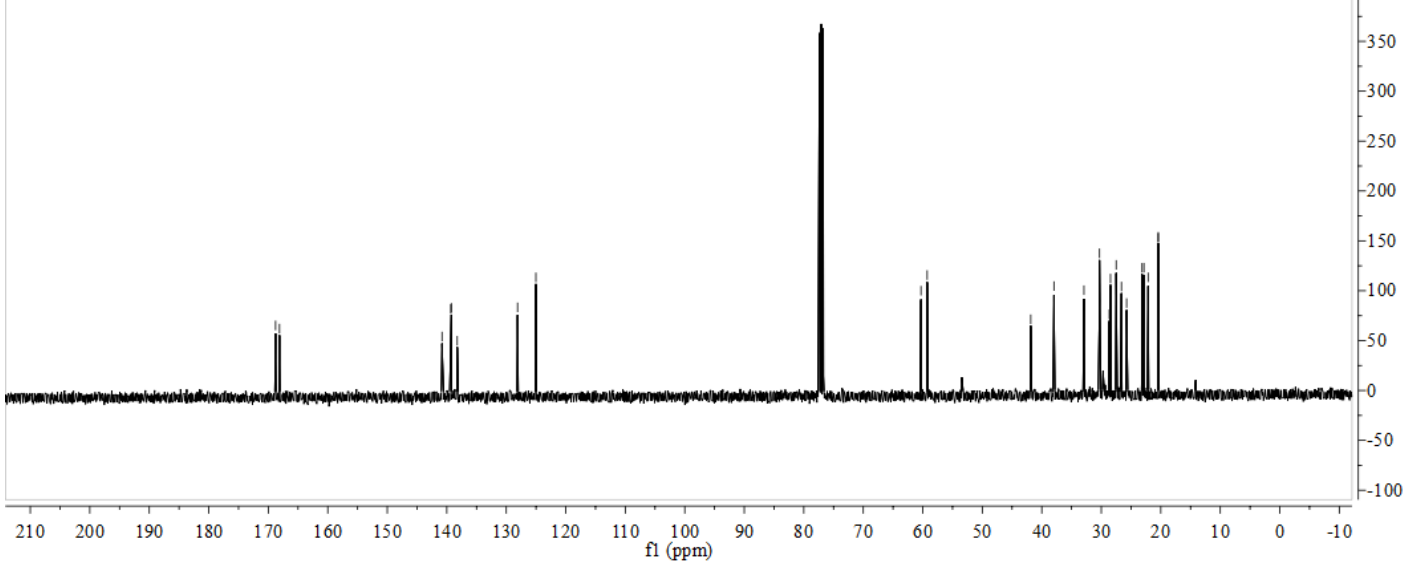


Figure S12. The ${ }^{1} \mathrm{H}$ NMR spectrum of compound 6 in $\mathrm{CDCl}_{3}(500 \mathrm{MHz})$

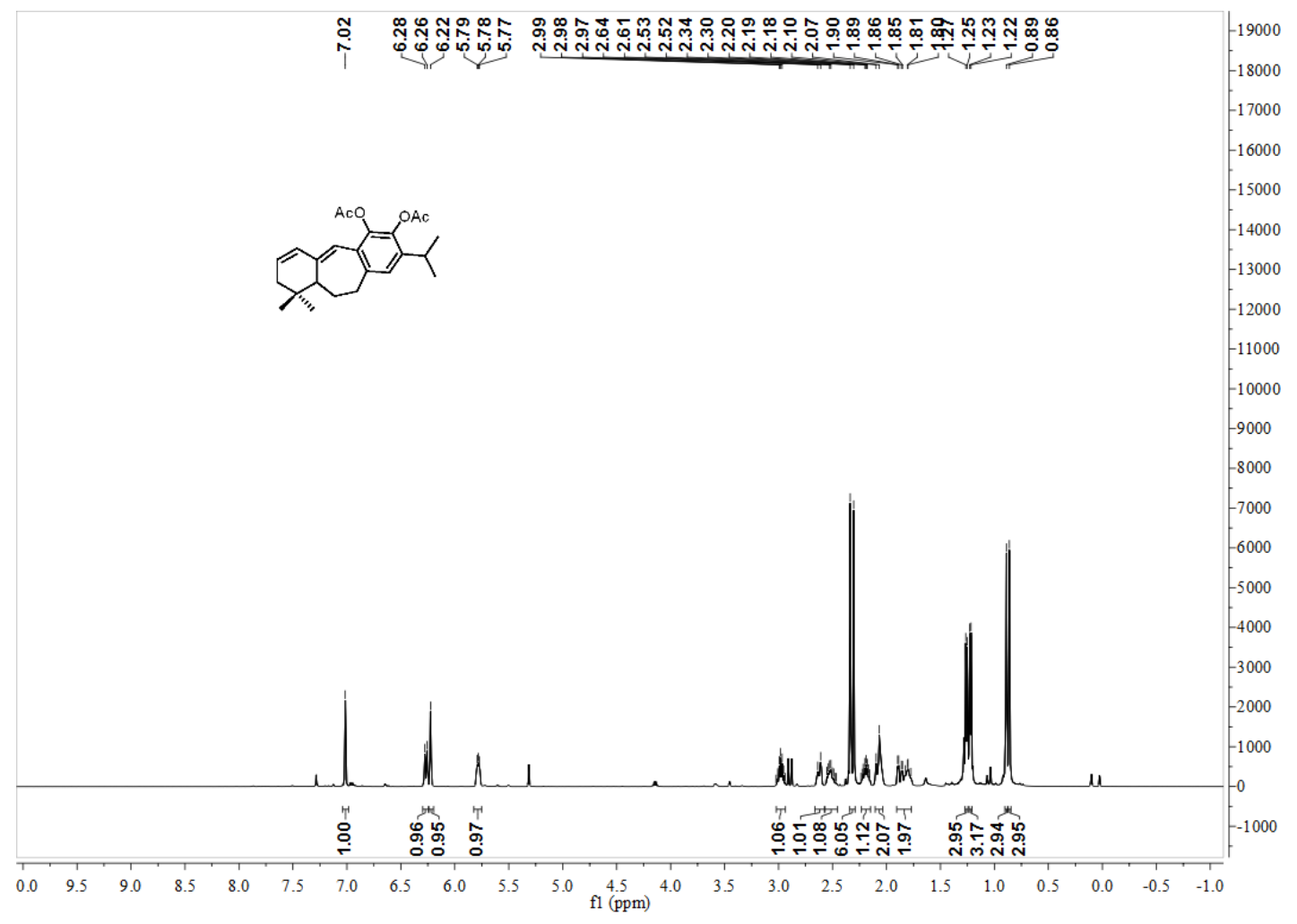

Figure S13. The ${ }^{13} \mathrm{C}$ NMR spectrum of compound 6 in $\mathrm{CDCl}_{3}(126 \mathrm{MHz})$

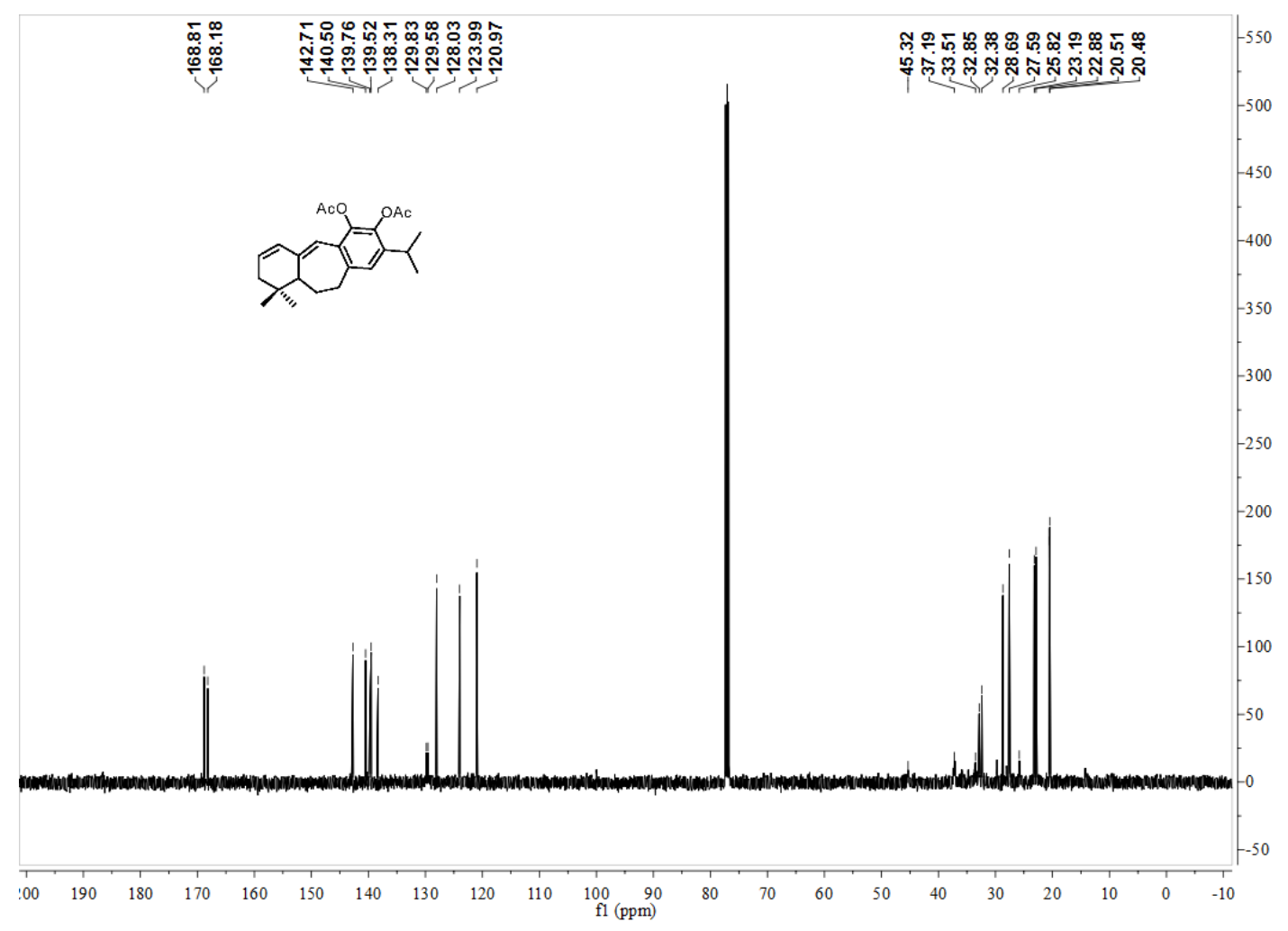


Figure S14. The ${ }^{1} \mathrm{H}$ NMR spectrum of compound 7 in $\mathrm{CDCl}_{3}(400 \mathrm{MHz})$

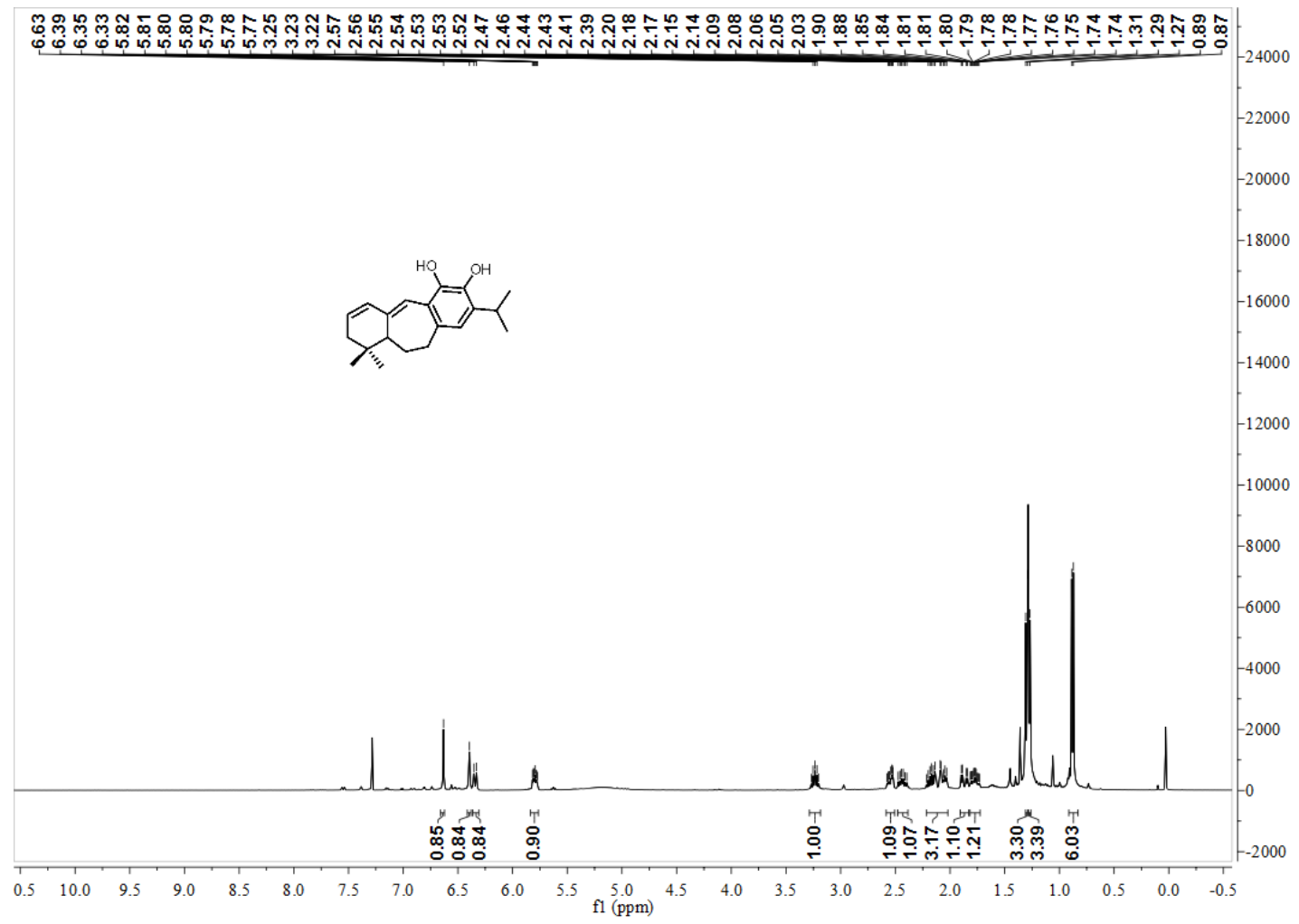

Figure S15. The ${ }^{13} \mathrm{C}$ NMR spectrum of compound 7 in $\mathrm{CDCl}_{3}(101 \mathrm{MHz})$

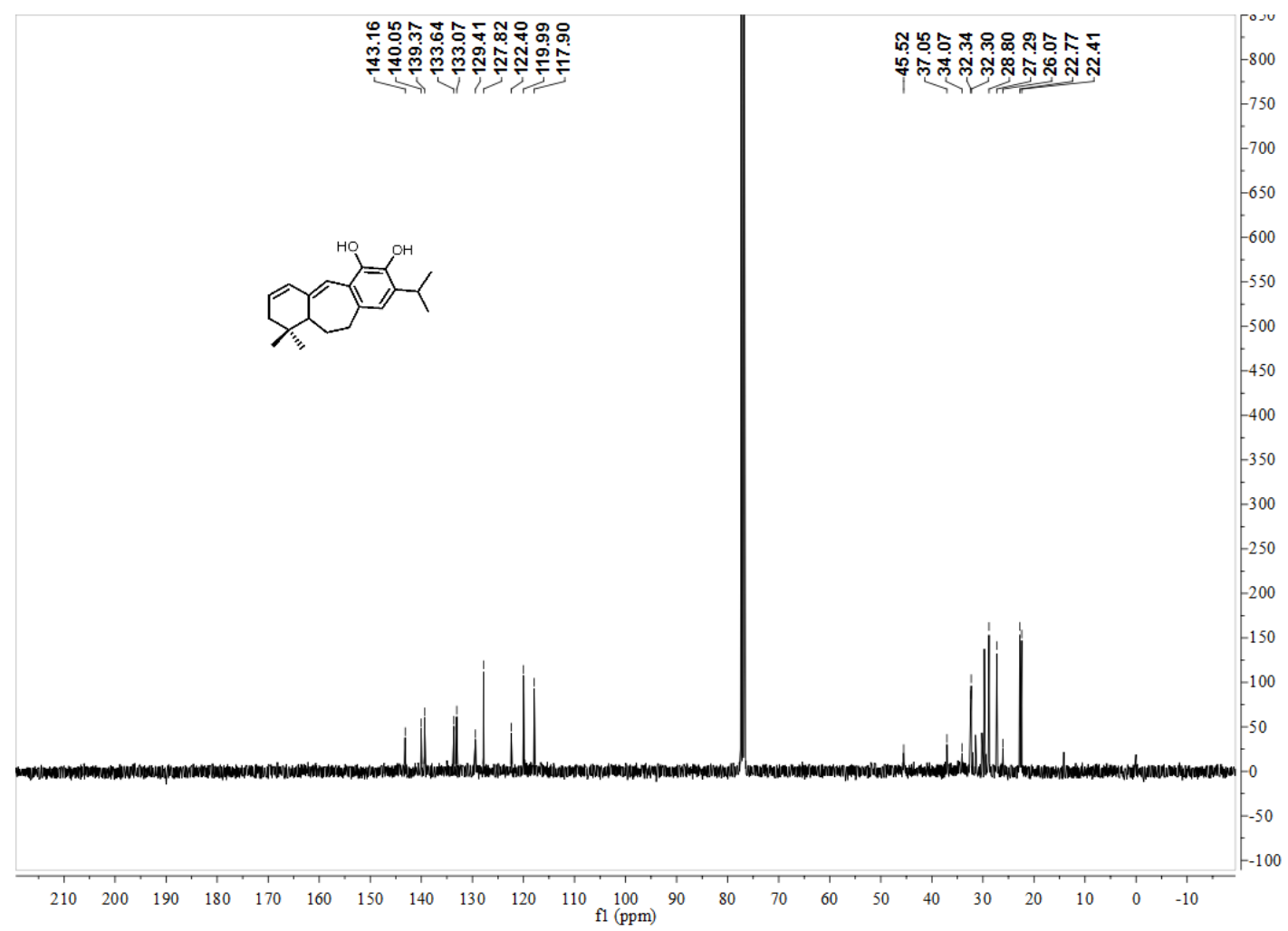


Figure S16. The ${ }^{1} \mathrm{H}$ NMR spectrum of compound 8 in $\mathrm{CDCl}_{3}(400 \mathrm{MHz})$

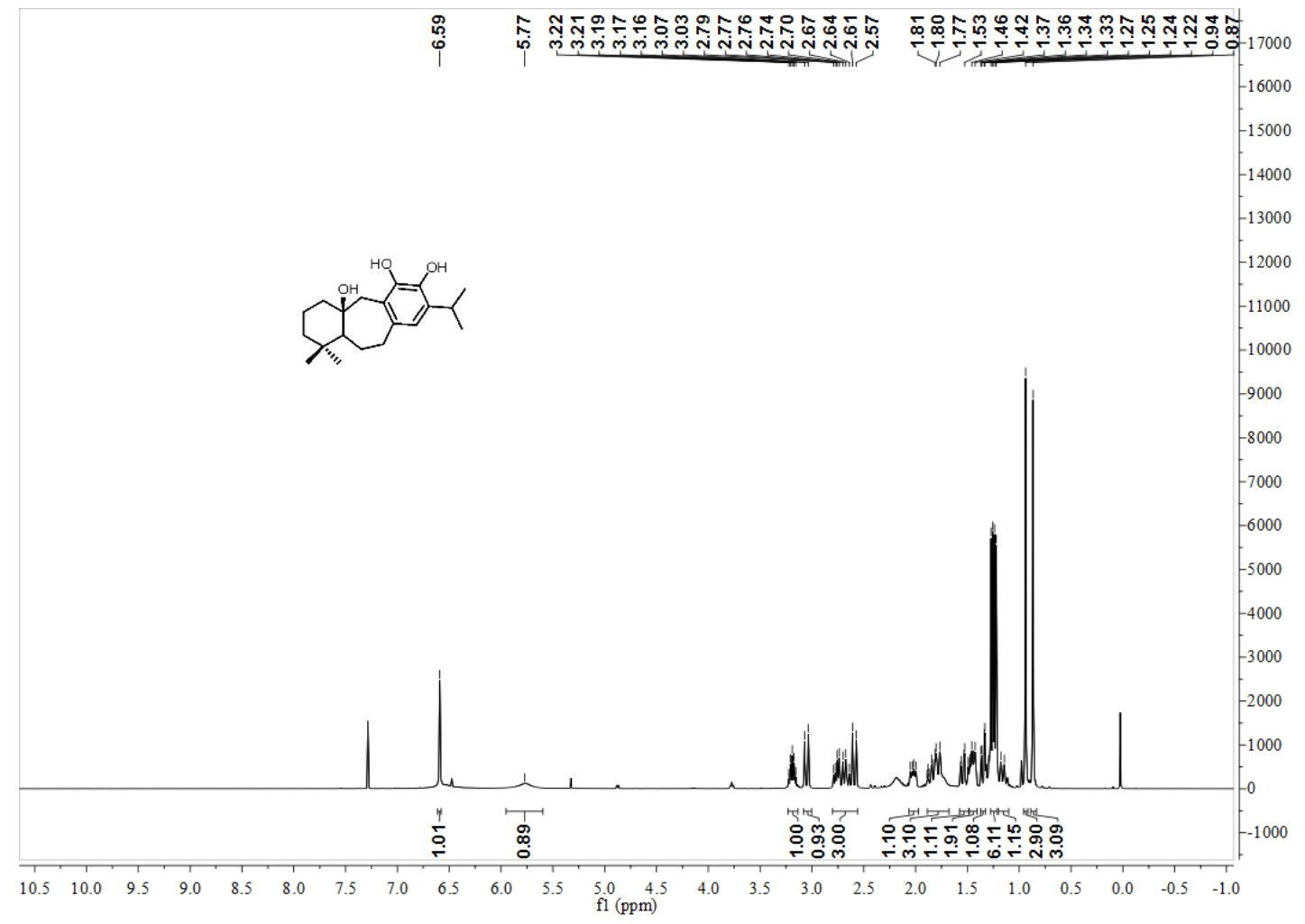

Figure S17. The ${ }^{13} \mathrm{C}$ NMR spectrum of compound 8 in $\mathrm{CDCl}_{3}(101 \mathrm{MHz})$

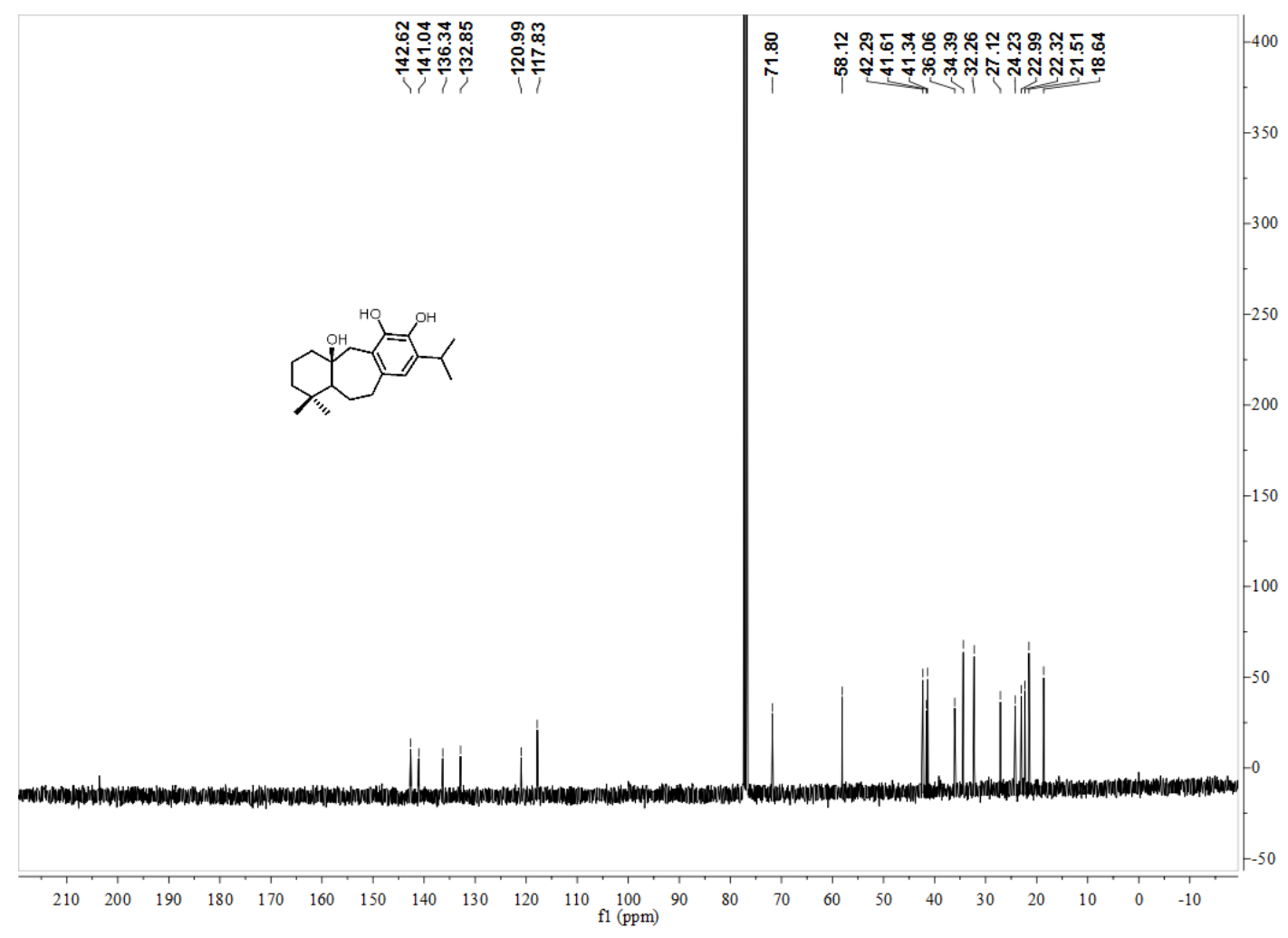


Figure S18. The ${ }^{1} \mathrm{H}$ NMR spectrum of compound 9 in $\mathrm{CDCl}_{3}(400 \mathrm{MHz})$

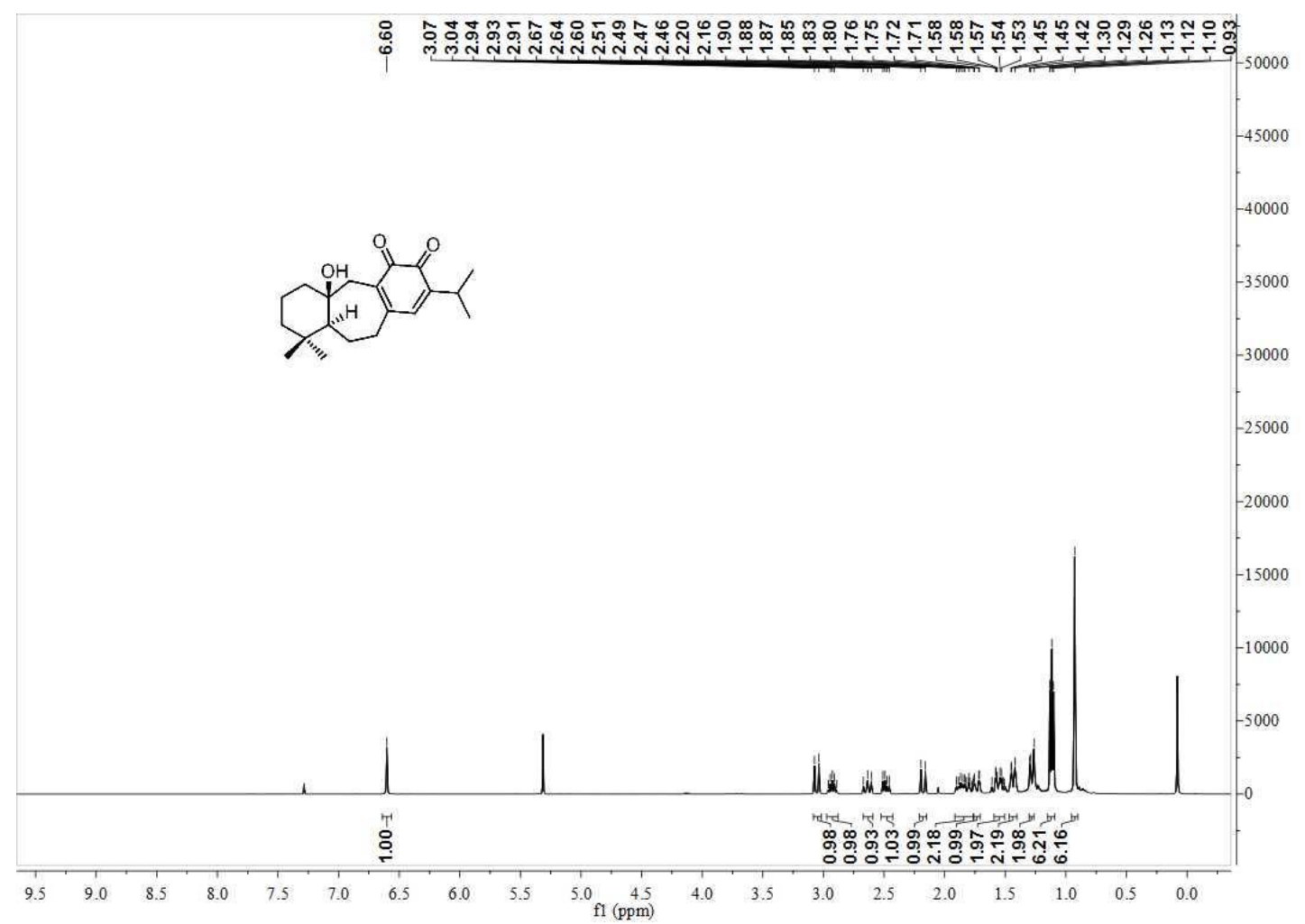

Figure S19. The ${ }^{13} \mathrm{C}$ NMR spectrum of compound 9 in $\mathrm{CDCl}_{3}(101 \mathrm{MHz})$

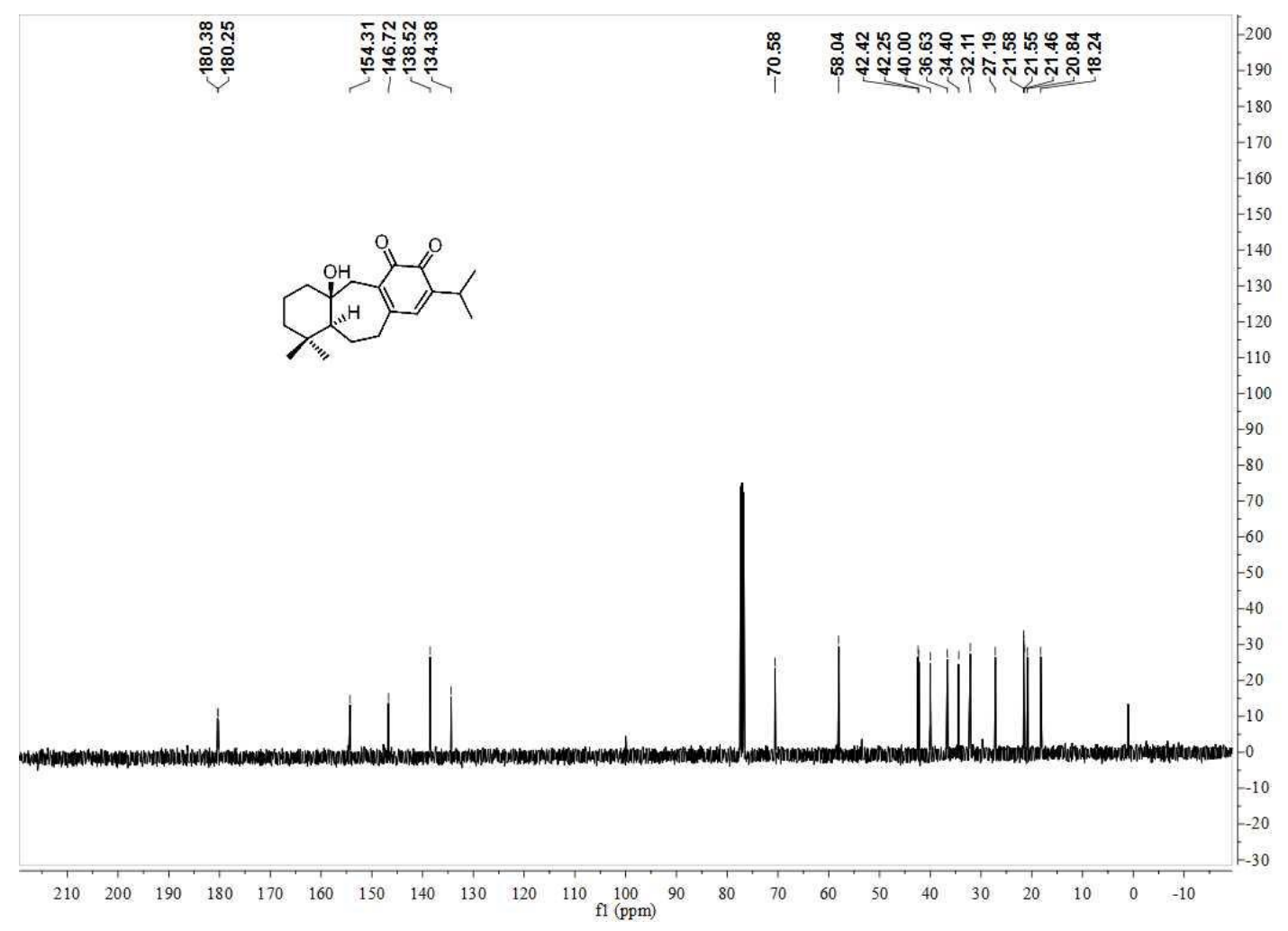


Figure S20. The ${ }^{1} \mathrm{H}$ NMR spectrum of compound 10 in $\mathrm{CDCl}_{3}(400 \mathrm{MHz})$

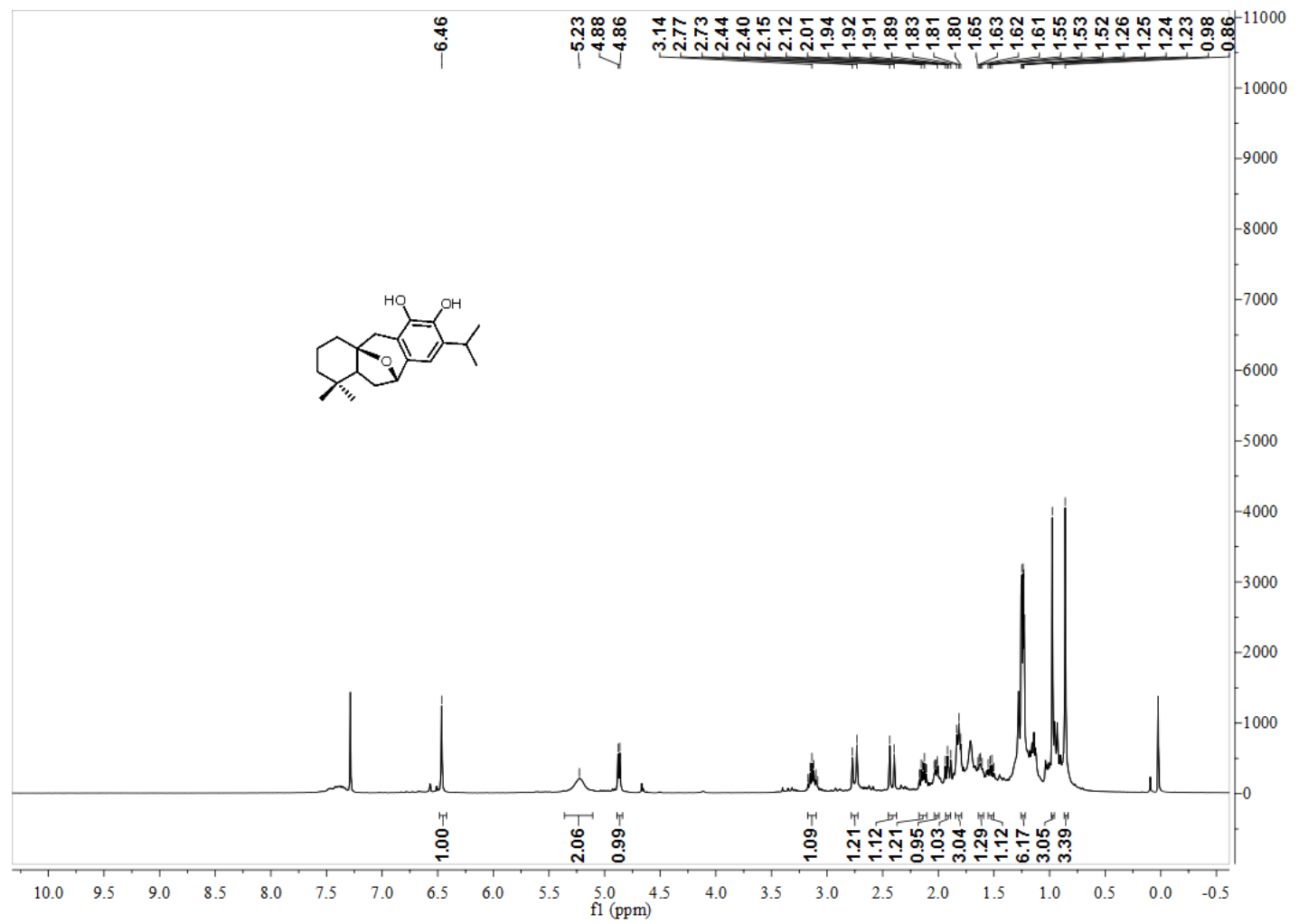

Figure S21. The ${ }^{13} \mathrm{C}$ NMR spectrum of compound 10 in $\mathrm{CDCl}_{3}(101 \mathrm{MHz})$

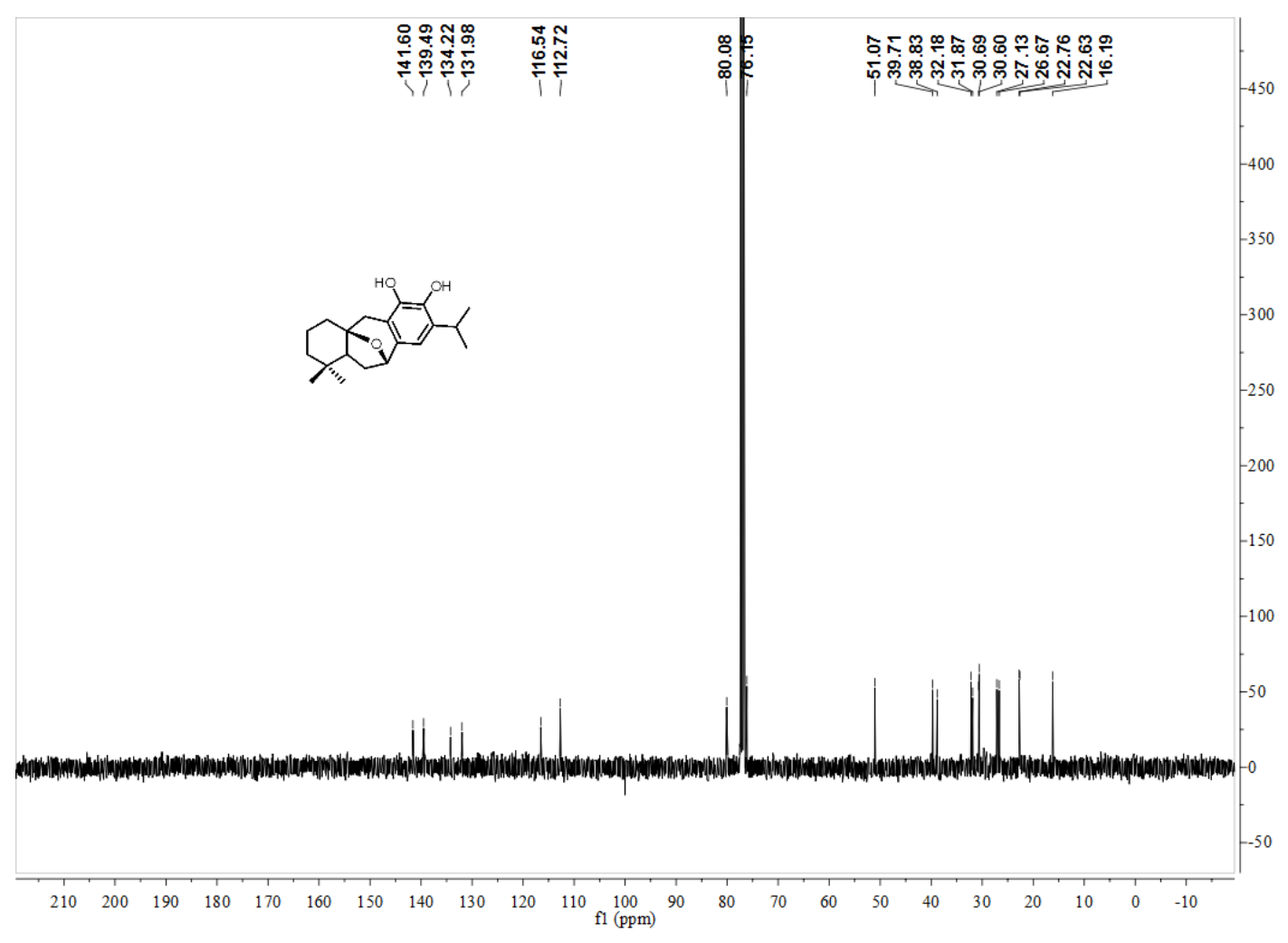


Figure S22. The ${ }^{1} \mathrm{H}$ NMR spectrum of compound 11 in $\mathrm{CDCl}_{3}(400 \mathrm{MHz})$

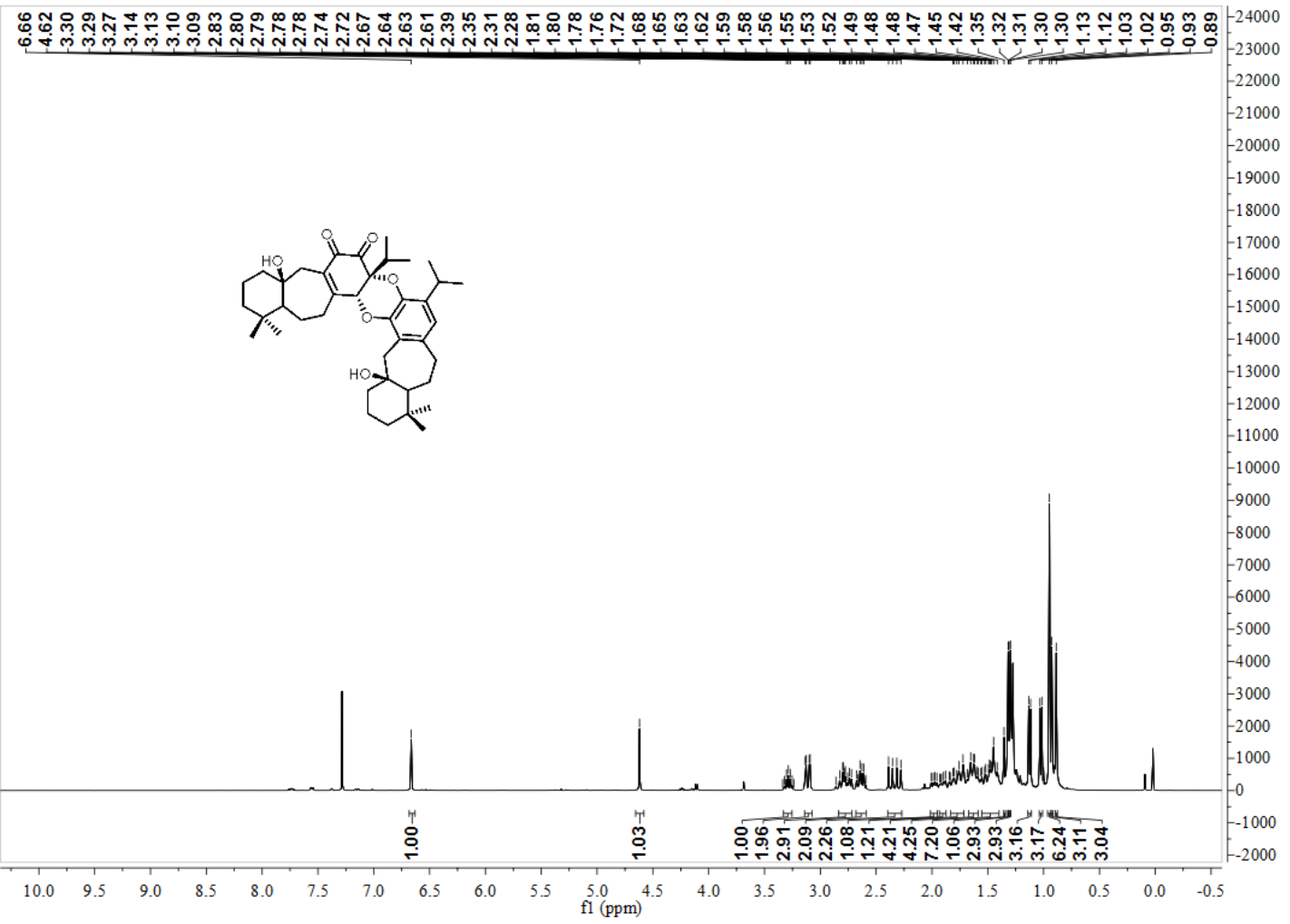

Figure S23. The ${ }^{13} \mathrm{C}$ NMR spectrum of compound 11 in $\mathrm{CDCl}_{3}(101 \mathrm{MHz})$

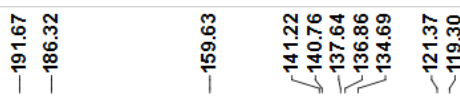

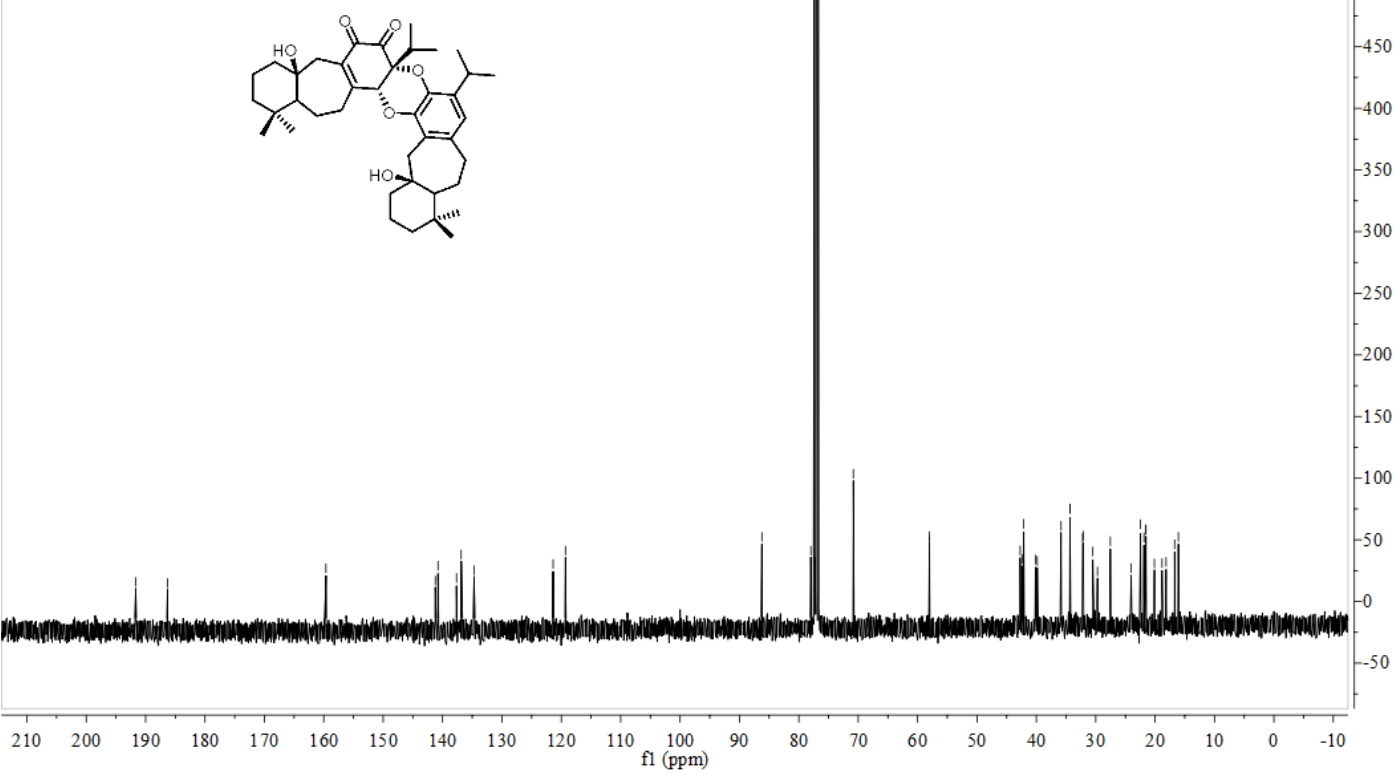

ส i क्ष 
Figure S24. The ${ }^{1} \mathrm{H}$ NMR spectrum of compound 12 in $\mathrm{CDCl}_{3}(500 \mathrm{MHz})$

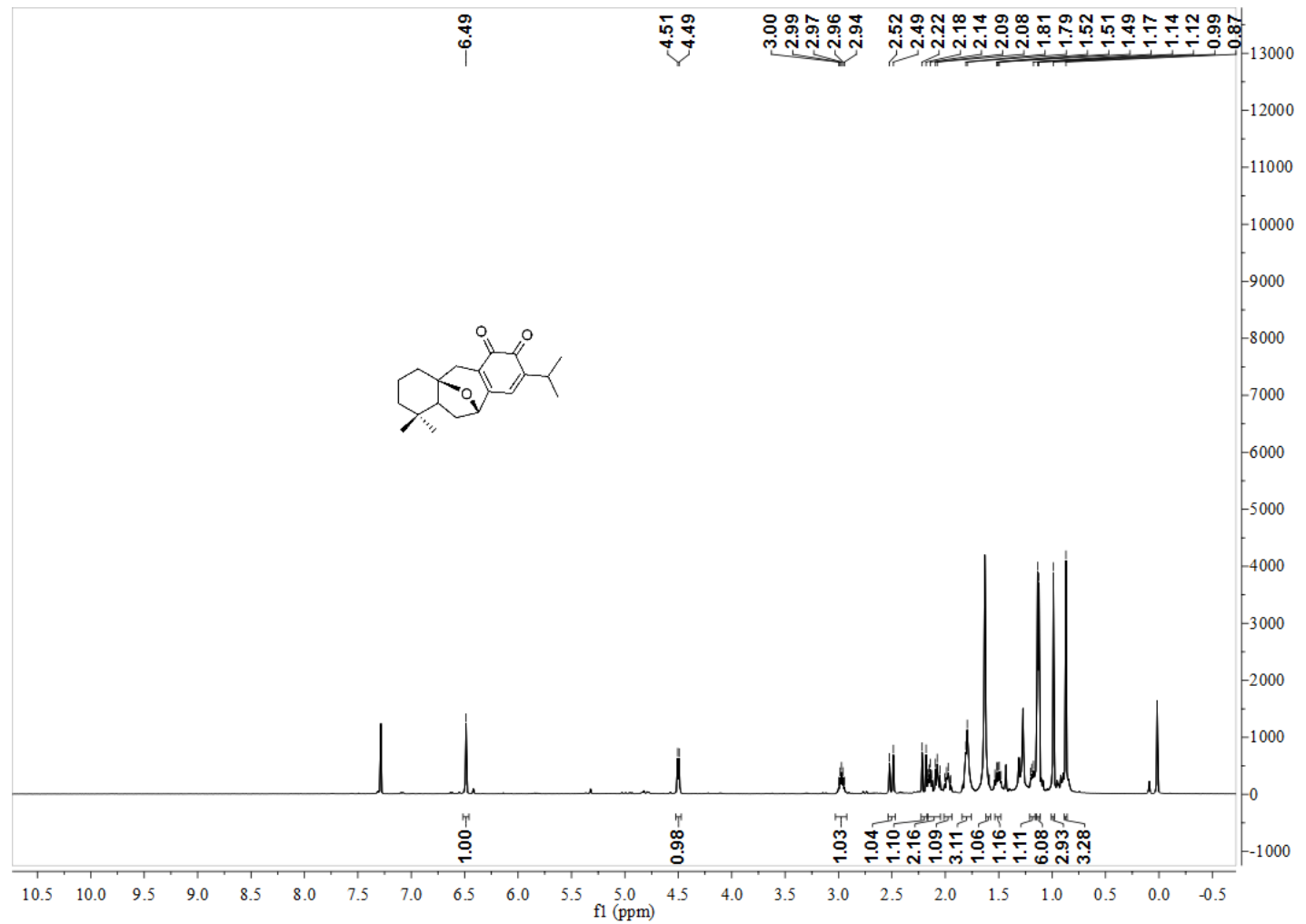

Figure S25. The ${ }^{13} \mathrm{C}$ NMR spectrum of compound 12 in $\mathrm{CDCl}_{3}(126 \mathrm{MHz})$

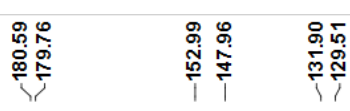

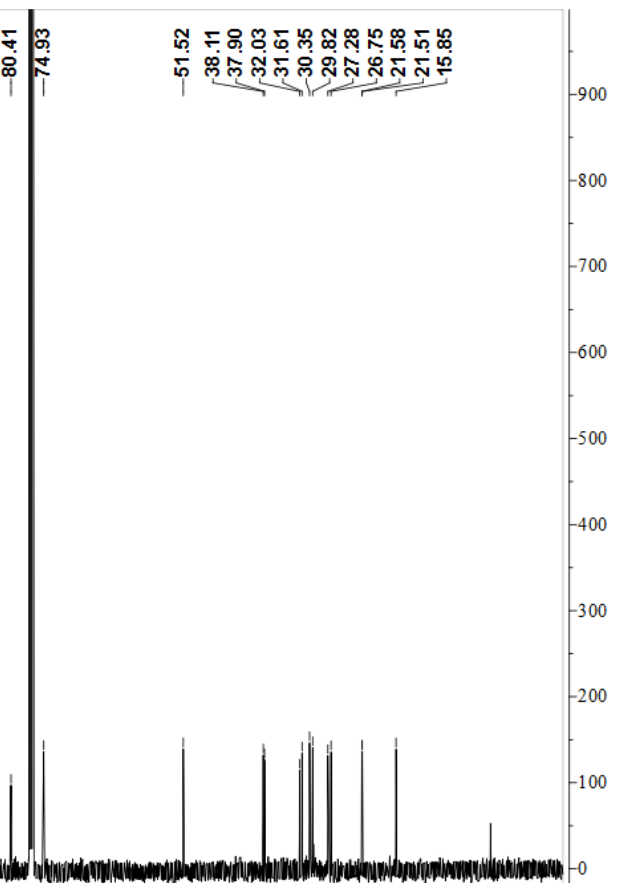

$\begin{array}{llllllllllll}210 & 200 & 190 & 180 & 170 & 160 & 150 & 140 & 130 & 120 & 110 \underset{\mathrm{fl}(\mathrm{ppm})}{100} 90\end{array}$

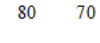

